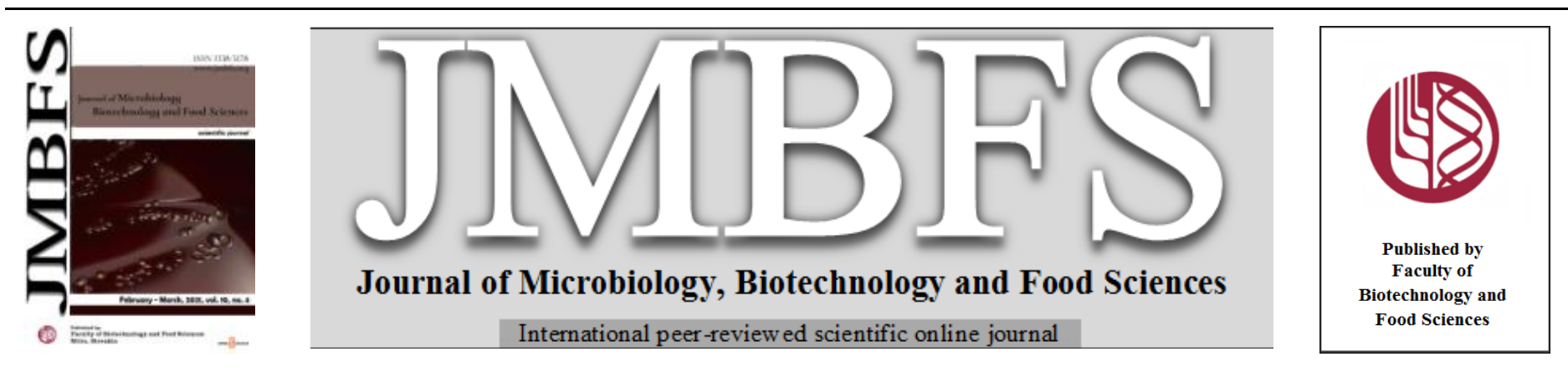

\title{
MOLECULAR MODELLING DESIGN AND OPIOID BINDING AFFINITY EVALUATION OF NEW 4-CHROMANONE DERIVATIVES
}

\author{
Mohammed Oday Ezzat ${ }^{1}$ and Basma M. Abd Razik ${ }^{2}$
}

Address(es):

${ }^{1}$ Department of Chemistry, College of Education for Women, University of Anbar, 31001, Ramadi, Anbar, Iraq. ${ }^{2}$ Department of Pharmaceutical Chemistry, College of Pharmacy, Mustansiriyah University, 10001, Baghdad, Iraq.

*Corresponding author: edw.mohamed_oday@uoanbar.edu.iq

doi: $10.15414 / j m b f s .2021 .10 .4 .531-535$

\section{ARTICLE INFO}

Received 24. 6. 2020

Revised 23. 9.2020

Accepted 24. 9. 2020

Published 1.2. 2021

Regular article

open $\partial_{\text {ACCESS }}$

\section{ABSTRACT}

The pharmacotherapy treatment of pain is an active and motivated area of investigation for treatment with free side effects. This paper presents the docking ability of twenty-five analogues of 4-Chromanone derivatives inside the crystal structure of $\mu$ opioid receptor to estimate the binding affinity of each derivative. Molecular modelling design approach applied to identify the effective substation position with generation of 989 novel 4-Chromanone derivatives. The final result of the most active twenty novel 4-Chromanone derivatives with docking affinity range $(-9.89$ to -9.34$) \mathrm{kcal} / \mathrm{mol}$ were selected as promising hit ligand drugs comparing with morphine docking affinity at $(-6.02) \mathrm{kcal} / \mathrm{mol}$.

Keywords: Molecular modelling, docking affinity, analgesic activity, scaffold lead

\section{INTRODUCTION}

Pain (or in particular chronic pain) remains the most significant an ongoing global health problem and it is the essential reason why people need medical care leading to decrees the productivity and life quality with socioeconomic problems. Nowadays, there are many available efficient analgesics and painkiller drugs like opioids and nonsteroidal anti-inflammatory drugs (NSAIDs) used in pain treatments, but the main limitation reason of use in therapy is related to their various side effects (Verma $\boldsymbol{e t}$ al., 2018). For that, there is a serious need to design and discover new substitutional drugs free of undesirable side effects (Yin et al., 2016). Moreover, the mechanism of pain relief (analgesic or antinociceptive) mainly is involved with the activation of opioid receptor (all four types) by endogenous or exogenous ligands accompanying with many physiological and behavioral effects such as sedation, euphoria, anxiety, respiratory depression, and gastrointestinal transit inhibition (Balcha \& Abdela, 2017; Dahan et al., 2018). Chromans (or chromenes) are unique class of bioactive compounds consisting of benzene and pyran fused ring called benzopyrans. The flavones family includes isoflavones, flavonoids, and coumarins have been intensively studied as constituents containing benzopyran ring (Hu et al., 2016). Chromene derivatives possess various pharmacological activities such as antitubercular, antivascular, antimicrobial, anti-inflammatory, antioxidant, TNF- $\alpha$ inhibitor, antitumor, antiviral, antifungal, anticoagulant, antispasmolytic, estrogenic, anthelminthic, anti-HIV, herbicidal, analgesic, and anticonvulsant activity (da Silva et al., 2014; Fadda et al., 2012; Hussain et al., 2014; Mladenović et al., 2010; Mungra et al., 2011; Ratnakar Reddy et al., 2014; Sankar et al., 2017). Moreover, 4-Chromanone (or chroman-4-one) is the most common name for the dihydrobenzopyranone. Up to 1971, many of this compounds group were indexed in Chemical Abstracts bulletin as 4chromanones, but since that year the name has been changed to 2,3-dihydro-4H1-benzopyran-Cones (Butler et al., 2010; Wen et al., 2016).

In the field of combinatorial chemistry, scaffold lead hopping is a modern applicable approach refers to the attempt to discover of new medical molecules with higher better or similar bioactivities to the original molecules structures (Zhao, 2007). Many computational methods have been applied to design and generate multi molecules structures by chemical group replacement to achieve new compound similar in skeleton to the active drug to with better activities (Aysha et al., 2014; Brown \& Jacoby, 2006). These methods includes and subdivide to virtual screening, de novo molecular design, topology similarity, pharmacophore search and shape similarity search (Eckert \& Bajorath, 2007; Khedkar et al., 2007; Klebe, 2006). In particular, the main aims of chemical group replacement to prevent many biological, chemical, or even intellectual side effects associated to the scaffold of currently used drugs (Abd Razik et al., 2020; Mehdy et al., 2018). In addition, this approach is usually used to enhance ADMET (absorption, distribution, metabolism, excretion, and toxicity) molecule profile and the potency of targeted activity by generating series of molecules as an analogous of the active drug (Lo et al., 2018). In this paper, a series of 4Chromanone analogues with analgesic activity was collected from literatures and there binding affinity inside $\mu$ opioid receptor was computationally evaluate (Higgs et al., 2013; Orazbekov et al., 2018). Next, model evaluation and chemical group replacement at selected position was applied to create new 4 Chromanone analogues with higher antinociceptive activity and lower undesirable side effects. The higher active twenty novel 4-Chromanone derivatives were selected as promising hit ligand drugs comparing with best drug for pain treatment (Morphine).

\section{COMPUTATIONAL METHOD}

A total of 25 4-Chromanone derivatives structures was obtained from literatures and the $3 \mathrm{D}$ derivative conformations was drawn by using ChemDraw16.0 program under ChemOffice package (ChemOffice, 2016). Next step, geometry optimization was perform by MM+ force field using Hyperchem program version 8.0 (Coleman \& Arumainayagam, 1998) and saved as .mol file format in sprite files. Furthermore, an additional geometry optimization by semi-empirical approach was applied for RM1 (Recife Model 1) (Rocha et al., 2006). To this step the lowest energy conformation of each molecule is saved as .sdf file format and optimized by using Spartan 14.0 software under windows (Spartan, 2014) with Monte Carlo approach with 100 cycles of optimization, 1000 interactions (Cohen, 1996). Molecular modeling design and molecular docking study were performed by using Glide docking software (Maestro 11.4) under Schrodinger package software (Schrodinger, 2018) for the preparation, minimization and docking studies running on Windows 7 Service Pack 1 operating system on $\mathrm{Hp}$ Precision T-1580 workstation (Intel (R) Core (TM) i7 CPU 896 @ 3.5GHz, 16 GB RAM, 1 TB HD). The crystal structures of active $\mu$ opioid receptor and agonist ligand was obtained from Protein Data Bank under PDB code: 5C1M with crystallographic resolution of 2.1. The receptor preparation steps were applied by ProPrep tool to optimize and protein minimization. This tool used to fill up any missing amino acids, removing of water molecules and ligands with improving of structure resolution. Ligand preparation applied by using LigPrep tool before docking to identify the best orientation and probable ionization position with adding hydrogen atom to achieve lowest energy conformations of each ligand by using OPLS 2005 force field. The size of receptor grid box adjusted to $50 \times 50 \times 50 \AA$ with a partial atomic charge of 0.27 and during 
docking process the receptor kept rigid and ligands were flexible. The best docked orientation and RMSD between protein crystal structure was saved and in order to generate several derivatives with diverse fragment the automated fragment replacement processes was applied. All derivatives were generated and saved by Custom R-Group Enumeration approach under Maestro software by the replacement of hydrogen atom in compound 6

\section{RESULTS AND DISCUSSION}

Over the past decades, opioid receptor has received the most permanent attention as a prominent target for new drug design and discovery due to its essential role in mediating of multi pharmacological issues subjected to behavioral and neurophysiological, including addictive behavior, pain sense, and gastrointestinal motility physiology (Pasternak, 2014). Thus, there has been intensive focus on the design and discovery of novel active ligands toward opioid receptor with high potential efficient therapeutics (Greedy et al., 2013). The successful crystallization process of $\mu$ opioid receptor structure in 2015 inspire the ability to estimate the structure activity relationships and binding affinity between ligand and human $\mu$ opioid receptor as the target to achieve new painkiller drugs (Huang et al., 2015). In this present work, the theoretical binding affinity application and molecular modeling design combination approaches for the discovery of novel molecules as agonist ligands at active site of human $\mu$ opioid receptor. The result of these approaches is a total of twenty-five 4-Chromanone derivatives collected from literatures and docked inside active site of human $\mu$ opioid receptor to evaluate the binding affinity of each molecule as shown in table 1 .

Table 1 Docking score of substituted 4-Chromanone derivatives collected from literatures<smiles>[R]c1ccc(C2Oc3c([R6])c([R])c([R6])c([R5])c3C(=O)C2[R3])c([R4])c1[R3]</smiles><smiles>[R3]c1ccc(-c2oc3c([R6])c([R])c([R6])c([R5])c3c(=O)c2[R3])c([R1])c1[R3]</smiles>

A

B

\begin{tabular}{|c|c|c|c|c|c|c|c|c|c|c|}
\hline Compound & Moiety & $\mathbf{R}_{3}$ & $\mathbf{R}_{5}$ & $\mathbf{R}_{6}$ & $\mathbf{R}_{7}$ & $\mathbf{R}_{8}$ & $\mathbf{R}_{2}$ & $\mathbf{R}_{3}{ }^{\prime}$ & $\mathbf{R}_{4}$ & Docking Score in kcal/mol \\
\hline 1 & $\mathrm{~A}$ & $\mathrm{H}$ & $\mathrm{H}$ & $\mathrm{H}$ & $\mathrm{H}$ & $\mathrm{H}$ & $\mathrm{H}$ & $\mathrm{H}$ & $\mathrm{H}$ & -6.84 \\
\hline 2 & A & $\mathrm{H}$ & $\mathrm{OH}$ & $\mathrm{H}$ & $\mathrm{OH}$ & $\mathrm{H}$ & $\mathrm{H}$ & $\mathrm{OH}$ & $\mathrm{OCH}_{3}$ & -6.95 \\
\hline 3 & A & $\mathrm{H}$ & $\mathrm{OH}$ & $\mathrm{H}$ & $\mathrm{OH}$ & $\mathrm{H}$ & $\mathrm{H}$ & $\mathrm{H}$ & $\mathrm{OH}$ & -6.09 \\
\hline 4 & $\mathrm{~B}$ & $\mathrm{H}$ & $\mathrm{H}$ & $\mathrm{H}$ & $\mathrm{H}$ & $\mathrm{H}$ & $\mathrm{H}$ & $\mathrm{H}$ & $\mathrm{H}$ & -6.38 \\
\hline 5 & B & $\mathrm{H}$ & $\mathrm{OH}$ & $\overline{\mathrm{H}}$ & $\mathrm{OH}$ & $\mathrm{H}$ & $\mathrm{H}$ & $\mathrm{OH}$ & $\mathrm{OCH}_{3}$ & -7.63 \\
\hline 6 & B & $\mathrm{OH}$ & $\mathrm{OH}$ & $\mathrm{H}$ & $\mathrm{OH}$ & $\mathrm{H}$ & $\mathrm{H}$ & $\mathrm{OH}$ & $\mathrm{OH}$ & -8.36 \\
\hline 7 & B & $\mathrm{H}$ & $\mathrm{OH}$ & $\mathrm{H}$ & $\mathrm{OH}$ & $\mathrm{H}$ & $\mathrm{H}$ & $\mathrm{H}$ & $\mathrm{OH}$ & -6.96 \\
\hline 8 & B & $\mathrm{H}$ & $\mathrm{OH}$ & $\mathrm{H}$ & $\mathrm{OH}$ & $\mathrm{H}$ & $\mathrm{H}$ & $\mathrm{H}$ & $\mathrm{H}$ & -7.24 \\
\hline 9 & B & $\mathrm{H}$ & $\mathrm{H}$ & $\mathrm{CH}_{3}$ & $\mathrm{H}$ & $\mathrm{H}$ & $\mathrm{H}$ & $\mathrm{H}$ & $\mathrm{H}$ & -6.94 \\
\hline 10 & B & $\mathrm{H}$ & $\mathrm{H}$ & $\mathrm{NO}_{2}$ & $\mathrm{H}$ & $\mathrm{H}$ & $\mathrm{H}$ & $\mathrm{H}$ & $\mathrm{H}$ & -6.22 \\
\hline 11 & $\mathrm{~B}$ & $\mathrm{H}$ & $\mathrm{H}$ & $\mathrm{F}$ & $\mathrm{H}$ & $\mathrm{H}$ & $\mathrm{H}$ & $\mathrm{H}$ & $\mathrm{H}$ & -7.03 \\
\hline 12 & B & $\mathrm{H}$ & $\mathrm{H}$ & $\mathrm{Cl}$ & $\mathrm{H}$ & $\mathrm{H}$ & $\mathrm{H}$ & $\mathrm{H}$ & $\mathrm{H}$ & -6.57 \\
\hline 13 & B & $\mathrm{H}$ & $\mathrm{H}$ & $\mathrm{CH}_{3}$ & $\mathrm{H}$ & $\mathrm{H}$ & $\mathrm{H}$ & $\mathrm{CH}_{3}$ & $\mathrm{H}$ & -5.90 \\
\hline 14 & B & $\mathrm{H}$ & $\mathrm{H}$ & $\mathrm{CH}_{3}$ & $\mathrm{H}$ & $\mathrm{H}$ & $\mathrm{H}$ & $\mathrm{Br}$ & $\mathrm{H}$ & -5.98 \\
\hline 15 & B & $\mathrm{H}$ & $\mathrm{H}$ & $\mathrm{H}$ & $\mathrm{H}$ & $\mathrm{H}$ & $\mathrm{NO}_{2}$ & $\mathrm{H}$ & $\mathrm{H}$ & -4.68 \\
\hline 16 & $\mathrm{~B}$ & $\mathrm{H}$ & $\mathrm{H}$ & $\mathrm{H}$ & $\mathrm{H}$ & $\mathrm{H}$ & $\mathrm{H}$ & $\mathrm{NO}_{2}$ & $\mathrm{H}$ & -6.12 \\
\hline 17 & B & $\mathrm{H}$ & $\mathrm{H}$ & $\mathrm{H}$ & $\mathrm{H}$ & $\mathrm{H}$ & $\mathrm{H}$ & $\mathrm{Cl}$ & $\mathrm{H}$ & $\begin{array}{l}-6.89 \\
\end{array}$ \\
\hline 18 & $\mathrm{~B}$ & $\mathrm{H}$ & $\mathrm{H}$ & $\mathrm{H}$ & $\mathrm{H}$ & $\mathrm{H}$ & $\mathrm{H}$ & $\mathrm{Br}$ & $\mathrm{H}$ & -7.12 \\
\hline 19 & B & $\mathrm{H}$ & $\mathrm{H}$ & $\mathrm{H}$ & $\mathrm{H}$ & $\mathrm{H}$ & $\mathrm{H}$ & $\mathrm{CH}_{3}$ & $\mathrm{H}$ & -6.50 \\
\hline 20 & B & $\mathrm{H}$ & $\mathrm{H}$ & $\mathrm{H}$ & $\mathrm{H}$ & $\mathrm{H}$ & $\mathrm{H}$ & $\mathrm{H}$ & $\mathrm{NO}_{2}$ & $\begin{array}{l}-5.24 \\
\end{array}$ \\
\hline 21 & B & $\mathrm{H}$ & $\mathrm{H}$ & $\mathrm{H}$ & $\mathrm{H}$ & $\mathrm{H}$ & $\mathrm{H}$ & $\mathrm{H}$ & $\mathrm{F}$ & -5.65 \\
\hline 22 & B & $\mathrm{H}$ & $\mathrm{H}$ & $\mathrm{H}$ & $\mathrm{H}$ & $\mathrm{H}$ & $\mathrm{H}$ & $\mathrm{H}$ & $\mathrm{Br}$ & -5.59 \\
\hline 23 & B & $\mathrm{Br}$ & $\mathrm{H}$ & $\mathrm{H}$ & $\mathrm{H}$ & $\mathrm{H}$ & $\mathrm{H}$ & $\mathrm{NO}_{2}$ & $\mathrm{H}$ & -6.78 \\
\hline 24 & B & $\mathrm{Br}$ & $\mathrm{H}$ & $\mathrm{Br}$ & $\mathrm{H}$ & $\mathrm{H}$ & $\mathrm{H}$ & $\mathrm{H}$ & $\mathrm{H}$ & -6.63 \\
\hline 25 & A & $\mathrm{Br}_{2}$ & $\mathrm{H}$ & $\mathrm{H}$ & $\mathrm{H}$ & $\mathrm{H}$ & $\mathrm{H}$ & $\mathrm{H}$ & $\mathrm{H}$ & -4.32 \\
\hline Morphine & - & - & - & - & - & - & - & - & - & -6.02 \\
\hline
\end{tabular}

In this table, docking score affinity range is between $-4.32 \mathrm{kcal} / \mathrm{mol}$ for compound 25 to $-8.36 \mathrm{kcal} / \mathrm{mol}$ for compound 6 with $-6.02 \mathrm{kcal} / \mathrm{mol}$ for morphine to compare as positive control. These findings refer to the high interesting affinity of compound 6 to bind inside the active site pocket inside opioid receptor comparing with surrounded by the most important amino acids figure 1.

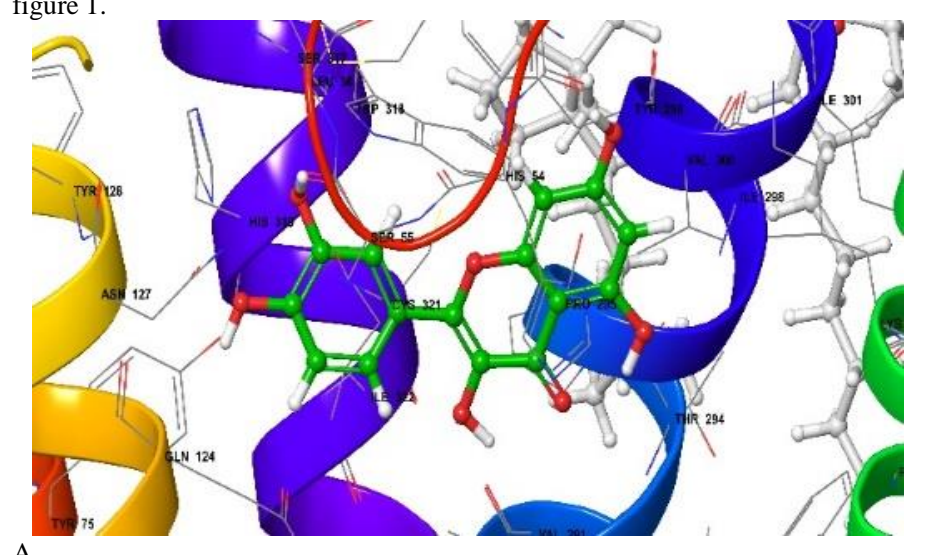

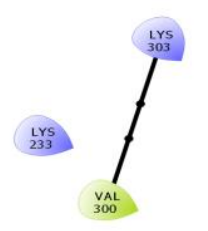

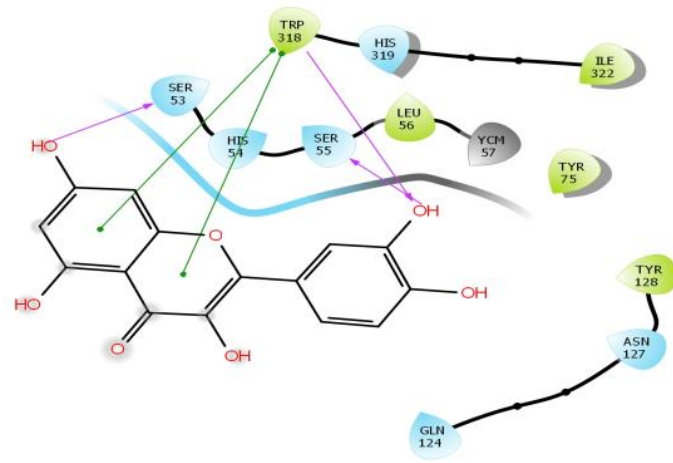

8 charged (negattve

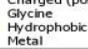
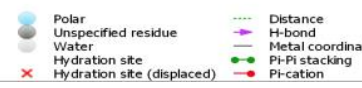

- Salt bridge
solvent exposire B

Figure 1 Compound 6 inside $\mu$ opioid receptor active site surrounded by amino acids (A) Compound 6 as ball and stick, receptor as ribbon. (B) Ligand interaction view of compound 6 
Inside receptor active site, compound 6 bind to TRP318 by tow Pi-Pi stacking interaction bond with both aromatic rings and forming $\mathrm{H}$-bond with hydroxyl group at $\mathrm{R}_{3}$ ' position. An additional two $\mathrm{H}$-bond formed between SER53 and SER55 with hydroxyl groups at $\mathrm{R}_{7}$ and $\mathrm{R}_{3}$ ' positions, respectively. Moreover, compound 6 inclosed by the following receptor active site amino acids: SER53, HIS54, SER55, LEU56, TYR75, GLN124, ASN127, TYR128, LYS233, VAL300, LYS303, TRP318, HIS319, and ILE322. Based on docking score result and QSAR model result evaluation, compound 6 was select as lead hit molecule for the next step to apply group replacement at selected effective group position. Figure 2 shows compound 6 (the best active compound) with desirable and undesirable reigns colored in green and yellow contours. These two reigns are labeled and colored depending on the destination of each area as following: Steric bulk undesirable is near yellow, steric bulk desirable is near green, positive charge desirable is near blue, and negative charge desirable is near red.

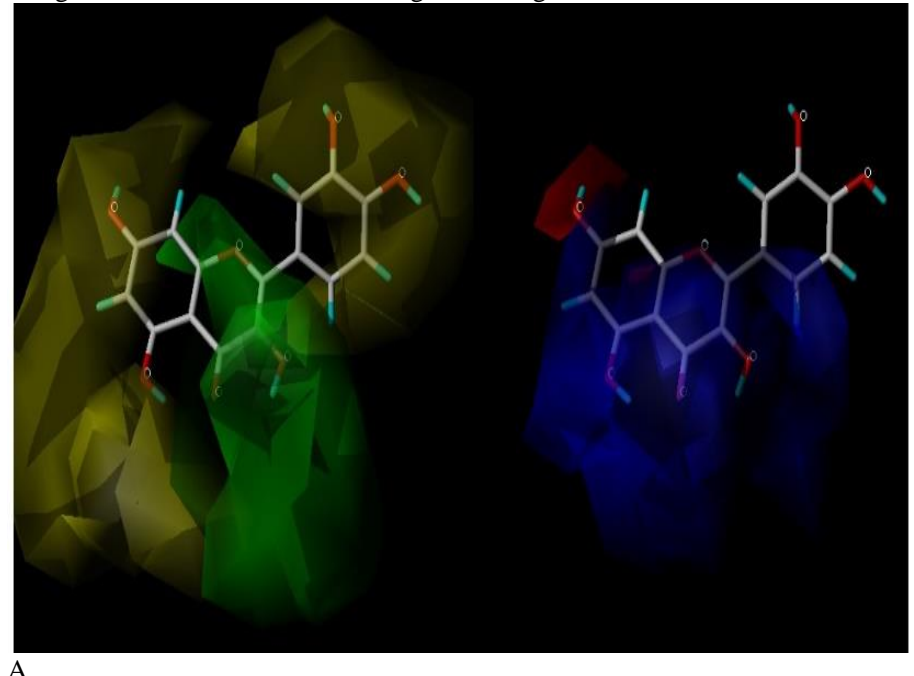<smiles></smiles>

B

Figure 2 Compound 6 (A) with desirable and undesirable contours reigns. (B) Substation position in red shaded cycle.

The green area is referring to the described best reign to replace with promising potency. From this point, hydroxyl group at $\mathrm{R}_{3}$ position was select to be replaced by many deferent chemical groups from database. After performing molecular group replacement generation, a total of 989 new 4-Chromanone derivatives were docked, recorded, and the higher best twenty molecules are listed dissenting in table 2. Among all derivatives, a total of sixty-eight compound were better than morphine. The substituted group replacement by alpha-methylstyrene group at position R3 result a high active compound N01 with high docking score $-9,89$ $\mathrm{kcal} / \mathrm{mol}$. This increasing in binding affinity companied with very good orientation inside the receptor active site and inclosed by important amino acids figure 3 .

Table 2 Docking score of the best generated twenty derivatives of compound 6<smiles>[R]Oc1c(-c2ccc(O)c(O)c2)oc2cc([2H])c(O)c(O)c2c1=O</smiles>

\begin{tabular}{|c|c|c|c|c|c|}
\hline Compound & $\mathbf{R}$ & $\begin{array}{l}\text { Docking Score } \\
\text { in } \mathrm{kcal} / \mathrm{mol}\end{array}$ & Compound & $\mathbf{R}$ & $\begin{array}{l}\text { Docking Score in } \\
\text { kcal/mol }\end{array}$ \\
\hline $\begin{array}{l}\text { N01 } \\
\text { 2-(3,4-dihydroxyphenyl)-5,7- } \\
\text { dihydroxy-3-(4-(prop-1-en-2- } \\
\text { yl)phenoxy)-4H-chromen-4-one }\end{array}$ & & -9.89 & $\begin{array}{l}\text { N11 } \\
\text { 2-(3,4-dihydroxyphenyl)- } \\
\text { 5,7-dihydroxy-3-(3- } \\
\text { isopropylphenoxy)-4H- } \\
\text { chromen-4-one }\end{array}$ & & -9.56 \\
\hline $\begin{array}{l}\text { N02 } \\
\text { 3-(4-(2-chloroethyl)phenoxy)-2- } \\
\text { (3,4-dihydroxyphenyl)-5,7- } \\
\text { dihydroxy-4H-chromen-4-one }\end{array}$ & & -9.88 & $\begin{array}{l}\text { N12 } \\
\text { 2-(3,4-dihydroxyphenyl)- } \\
\text { 3-(3-ethynyl-5- } \\
\text { fluorophenoxy)-5,7- } \\
\text { dihydroxy-4H-chromen-4- } \\
\text { one }\end{array}$ & & -9.54 \\
\hline $\begin{array}{l}\text { N03 } \\
\text { 2-(3,4-dihydroxyphenyl)-3-(3- } \\
\text { ethyl-5-methylphenoxy)-5,7- } \\
\text { dihydroxy-4H-chromen-4-one }\end{array}$ & & -9.86 & $\begin{array}{l}\text { N13 } \\
\text { 3-((6- } \\
\text { (difluoromethyl)pyridin-2- } \\
\text { yl)oxy)-2-(3,4- } \\
\text { dihydroxyphenyl)-5,7- } \\
\text { dihydroxy-4H-chromen-4- } \\
\text { one }\end{array}$ & & -9.52 \\
\hline $\begin{array}{l}\text { N04 } \\
\text { 3-(3,5-dichloro-4- } \\
\text { hydroxyphenoxy)-2-(3,4- } \\
\text { dihydroxyphenyl)-5,7- } \\
\text { dihydroxy-4H-chromen-4-one }\end{array}$ & & -9.85 & $\begin{array}{l}\text { N14 } \\
\text { 2-(3-((2-(3,4- } \\
\text { dihydroxyphenyl)-5,7- } \\
\text { dihydroxy-4-oxo-4H- } \\
\text { chromen-3- } \\
\text { yl)oxy)phenyl)acetonitrile }\end{array}$ & & -9.50 \\
\hline $\begin{array}{l}\text { N05 } \\
\text { (E)-2-(3,4-dihydroxyphenyl)- } \\
\text { 5,7-dihydroxy-3-(3- } \\
\text { ((methylimino)methyl)phenoxy)- } \\
\text { 4H-chromen-4-one }\end{array}$ & & -9.75 & $\begin{array}{l}\text { N15 } \\
\text { 2-(3-((2-(3,4- } \\
\text { dihydroxyphenyl)-5,7- } \\
\text { dihydroxy-4-oxo-4H- } \\
\text { chromen-3-yl)oxy)-5- } \\
\text { methylphenyl)acetonitrile }\end{array}$ & & -9.44 \\
\hline
\end{tabular}




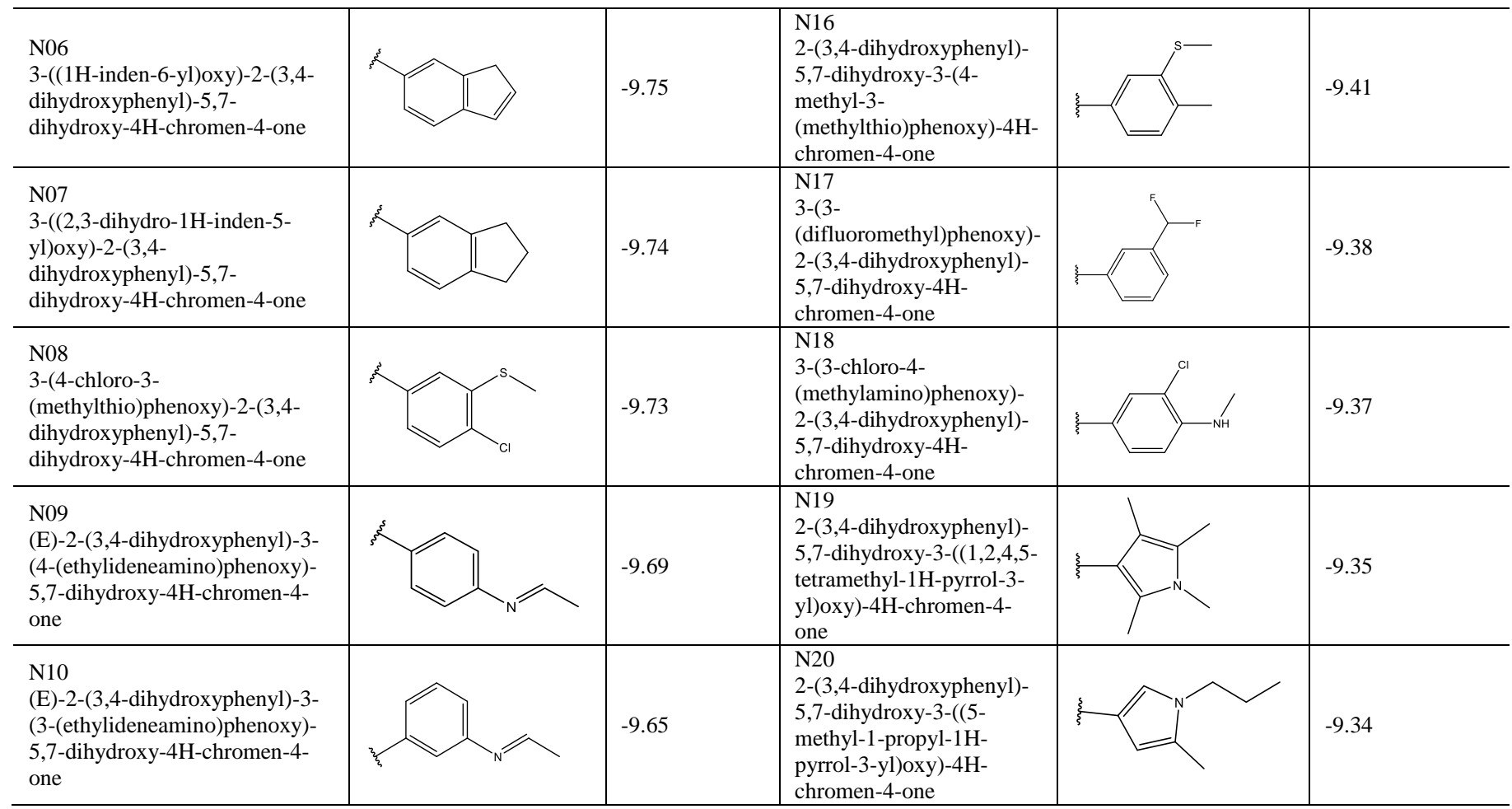
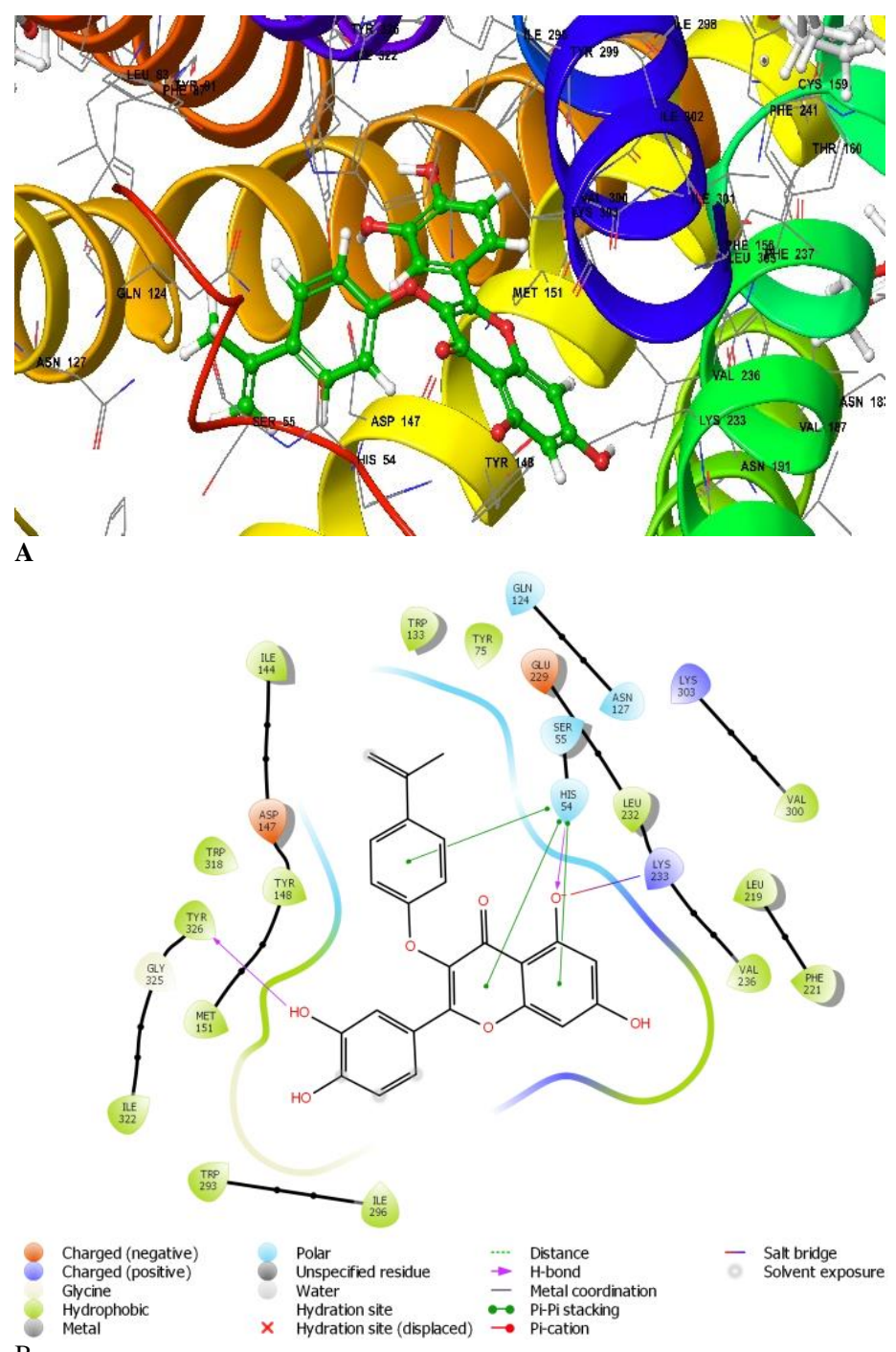

Figure 3 Compound N01 inclosed by most important amino acids inside human $\mu$ opioid receptor active site (A) Compound N01 as ball and stick, receptor as ribbon. (B) Ligand interaction view of compound N01.
Inside active site compound N01 bind by three Pi-Pi stacking interactions HIS54 from three aromatic rings. Another two interactions with hydroxyl group by $\mathrm{H}$ bond interactions with LYS233 and HIS54. Moreover, all the active important amino acids inclosed with this compound supported with the previous interactions. The existing of these interactions helps to increase the binding affinity and activity of any compound inclosed inside active site. In contrast, between many interesting and well-known $\mu$ opioid receptor active ligands, these twenty compounds consider as new novel chemical scaffolds. It is referring to that hits selection group replacement molecule approaches usually will provide better active compound than the compounds in virtual screening models.

\section{CONCLUSION}

In drug design, scaffold hopping is one of the best important approach in molecular discovery and design to improve potency or binding affinity selection. In this present paper, the result of applying this concept was a novel 4Chromanone analogues with higher pharmacological profile and binding affinity inside active site of human $\mu$ opioid receptor. This is materialized by high binding affinity among a total of sixty-eight compounds better than morphine within a range of $(-9.89$ to -9.34$) \mathrm{kcal} / \mathrm{mol}$ for the highest twenty compounds promoted with Pi-Pi stacking and H-bond interactions. Further biological and pharmacological evaluation is required to understand the side effects of all novel portentous drugs.

\section{REFERENCES}

Abd Razik, B. M., Ezzat, M. O., \& Al-Shohani, A. D. H. (2020). Molecular Docking and Design Study for Anticancer Activity of Flavonoid Derivatives Against Breast Cancer. Indian Drugs, 57(4), 7-14. https://doi.org/10.1016/inddru.2020.104141

Aysha, O. S., Mohammed, M. P., \& Dhamotharan, R. (2014). Insilico Identification of Potent Inhibitor from Andrographis Paniculata for ESBLs. International Journal of Advances in Applied Sciences, 3(3), 151-157. https://doi.org/10.11591/ijaas.v3.i3.pp151-157

Balcha, C., \& Abdela, N. (2017). Review of Rabies Preventions and Control. International Journal of Public Health Science (IJPHS), 6(4), 343 https://doi.org/10.11591/IJPHS.V6I4.10781

Brown, N., \& Jacoby, E. (2006). On scaffolds and hopping in medicinal chemistry. Mini Reviews in Medicinal Chemistry, 6(11), 1217-1229. https://doi.org/10.2174/138955706778742768

Butler, J. D., Conrad, W. E., Lodewyk, M. W., Fettinger, J. C., Tantillo, D. J., \& Kurth, M. J. (2010). Synthesis of Substituted Chromanones: An Organocatalytic Aldol/oxa-Michael Reaction. Organic Letters, 12(15), 3410-3413. https://doi.org/10.1021/ol101221c

Cohen, N. (1996). Guidebook on Molecular Modeling in Drug Design. https://doi.org/10.1016/s0753-3322(97)86919-3

Coleman, W. F., \& Arumainayagam, C. R. (1998). HyperChem 5 (by Hypercube, Inc.). Journal of Chemical Education, 75(4), 416. https://doi.org/10.1021/ed075p416 
da Silva, I. M., da Silva Filho, J., Santiago, P. B. G. da S., do Egito, M. S., de Souza, C. A., Gouveia, F. L., Ximenes, R. M., de Sena, K. X. da F. R., de Faria, A. R., Brondani, D. J., \& de Albuquerque, J. F. C. (2014). Synthesis and Antimicrobial Activities of 5-Arylidene-thiazolidine-2,4-dione Derivatives BioMed Research International, 2014, 1-8. https://doi.org/10.1155/2014/316082 Dahan, A., van der Schrier, R., Smith, T., Aarts, L., van Velzen, M., \& Niesters, M. (2018). Averting Opioid-induced Respiratory Depression without Affecting Analgesia. Anesthesiology, 128(5), 1027-1037. https://doi.org/10.1097/ALN.0000000000002184

Eckert, H., \& Bajorath, J. (2007). Molecular similarity analysis in virtual screening: foundations, limitations and novel approaches. Drug Discovery Today, 12(5-6), 225-233. https://doi.org/10.1016/j.drudis.2007.01.011

Fadda, A. A., Berghot, M. A., Amer, F. A., Badawy, D. S., \& Bayoumy, N. M (2012). Synthesis and Antioxidant and Antitumor Activity of Novel Pyridine Chromene, Thiophene and Thiazole Derivatives. Archiv Der Pharmazie, 345(5), 378-385. https://doi.org/10.1002/ardp.201100335

Greedy, B. M., Bradbury, F., Thomas, M. P., Grivas, K., Cami-Kobeci, G., Archambeau, A., Bosse, K., Clark, M. J., Aceto, M., Lewis, J. W., Traynor, J. R. \& Husbands, S. M. (2013). Orvinols with mixed kappa/mu opioid receptor agonist activity. Journal of Medicinal Chemistry, 56(8), 3207-3216. https://doi.org/10.1021/jm301543e

Higgs, J., Wasowski, C., Loscalzo, L. M., \& Marder, M. (2013). In vitro binding affinities of a series of flavonoids for $\mu$-opioid receptors. Antinociceptive effect of the synthetic flavonoid 3,3-dibromoflavanone in mice. Neuropharmacology, 72, 9-19. https://doi.org/10.1016/j.neuropharm.2013.04.020

Hu, N., Li, K., Wang, Z., \& Tang, W. (2016). Synthesis of Chiral 1, 4 Benzodioxanes and Chromans by Enantioselective Palladium-Catalyzed Alkene Aryloxyarylation Reactions. Angewandte Chemie International Edition, 55(16) 5044-5048. https://doi.org/10.1002/anie.201600379

Huang, W., Manglik, A., Venkatakrishnan, A. J., Laeremans, T., Feinberg, E. N Sanborn, A. L., Kato, H. E., Livingston, K. E., Thorsen, T. S., Kling, R. C., Granier, S., Gmeiner, P., Husbands, S. M., Traynor, J. R., Weis, W. I., Steyaert, J., Dror, R. O., \& Kobilka, B. K. (2015). Structural insights into $\mu$-opioid receptor activation. Nature, 315-321. https://doi.org/10.1038/nature14886

Hussain, M. K., Ansari, M. I., Yadav, N., Gupta, P. K., Gupta, A. K., Saxena, R., Fatima, I., Manohar, M., Kushwaha, P., Khedgikar, V., Gautam, J., Kant, R., Maulik, P. R., Trivedi, R., Dwivedi, A., Kumar, K. R., Saxena, A. K., \& Hajela K. (2014). Design and synthesis of $E R \alpha / E R \beta$ selective coumarin and chromene derivatives as potential anti-breast cancer and anti-osteoporotic agents. RSC Adv., 4(17), 8828-8845. https://doi.org/10.1039/C3RA45749D

Khedkar, S. A., Malde, A. K., Coutinho, E. C., \& Srivastava, S. (2007) Pharmacophore modeling in drug discovery and development: an overview. Medicinal Chemistry (Shariqah (United Arab Emirates)), 3(2), 187-197. https://doi.org/10.2174/157340607780059521

Klebe, G. (2006). Virtual ligand screening: strategies, perspectives and limitations. Drug Discovery Today, 11(13-14), 580-594. https://doi.org/10.1016/j.drudis.2006.05.012

Lo, Y.-C., Rensi, S. E., Torng, W., \& Altman, R. B. (2018). Machine learning in chemoinformatics and drug discovery. Drug Discovery Today, 23(8), 1538-1546. https://doi.org/10.1016/j.drudis.2018.05.010

Mehdy, M. A., Graziano, M., \& Piccinini, G. (2018). Simulation and modeling of silicon based single electron transistor. International Journal of Electrical and $\begin{array}{lll}\text { Computer } \quad \text { Engineering, } & \text { 8(2), 900-907. }\end{array}$ https://doi.org/10.11591/ijece.v8i2.pp900-907

Mladenović, M., Vuković, N., Sukdolak, S., \& Solujić, S. (2010). Design of Novel 4-Hydroxy-chromene-2-one Derivatives as Antimicrobial Agents Molecules, 15(6), 4294-4308. https://doi.org/10.3390/molecules 15064294

Mungra, D. C., Patel, M. P., Rajani, D. P., \& Patel, R. G. (2011). Synthesis and Identification of $\beta$-aryloxyquinolines and their pyrano[3,2-c]chromene Derivatives as a New Class of Antimicrobial and Antituberculosis Agents. European Journal of Medicinal Chemistry, 46(9), 4192-4200. https://doi.org/10.1016/j.ejmech.2011.06.022

Orazbekov, Y., Ibrahim, M. A., Mombekov, S., Srivedavyasasri, R., Datkhayev, U., Makhatov, B., Chaurasiya, N. D., Tekwani, B. L., \& Ross, S. A. (2018) Isolation and Biological Evaluation of Prenylated Flavonoids from Maclura pomifera. Evidence-Based Complementary and Alternative Medicine, 2018, 1-8. https://doi.org/10.1155/2018/1370368

Pasternak, G. W. (2014). Opiate pharmacology and relief of pain. Journal of Clinical Oncology: Official Journal of the American Society of Clinical Oncology, 32(16), 1655-1661. https://doi.org/10.1200/JCO.2013.53.1079

Ratnakar Reddy, K., Sambasiva Rao, P., Jitender Dev, G., Poornachandra, Y., Ganesh Kumar, C., Shanthan Rao, P., \& Narsaiah, B. (2014). Synthesis of novel 1,2,3-triazole/isoxazole functionalized $2 \mathrm{H}$-Chromene derivatives and their cytotoxic activity. Bioorganic \& Medicinal Chemistry Letters, 24(7), 1661-1663. https://doi.org/10.1016/j.bmcl.2014.02.069

Rocha, G. B., Freire, R. O., Simas, A. M., \& Stewart, J. J. P. (2006). RM1: A Reparameterization of AM1 for $\mathrm{H}, \mathrm{C}, \mathrm{N}, \mathrm{O}, \mathrm{P}, \mathrm{S}, \mathrm{F}, \mathrm{Cl}, \mathrm{Br}$, and I. Journal of Computational Chemistry, 27(10), 1101-1111. https://doi.org/10.1002/jcc.20425

Sankar, P. S., Divya, K., Padmaja, A., \& Padmavathi, V. (2017). Synthesis and
Antimicrobial Activity of Azetidinone and Thiazolidinone Derivatives from Azolylindolyl Schiff's Bases. Medicinal Chemistry, 7(11), 340-347. https://doi.org/10.4172/2161-0444.1000478

Verma, U. P., Abhaya, G., \& Disha, S. (2018). Role of Curcuma longa in the Management of Gingivitis. International Journal of Public Health Science (IJPHS), 7(3), 216. https://doi.org/10.11591/ijphs.v7i3.14830

Wen, G., Su, Y., Zhang, G., Lin, Q., Zhu, Y., Zhang, Q., \& Fang, X. (2016). Stereodivergent Synthesis of Chromanones and Flavanones via Intramolecular Benzoin Reaction. Organic Letters, 18(16), 3980-3983. https://doi.org/10.1021/acs.orglett.6b01767

Yin, Z. Y., Li, L., Chu, S. S., Sun, Q., Ma, Z. L., \& Gu, X. P. (2016) Antinociceptive effects of dehydrocorydaline in mouse models of inflammatory pain involve the opioid receptor and inflammatory cytokines. Scientific Reports, 6, 27129. https://doi.org/10.1038/srep27129

Zhao, H. (2007). Scaffold selection and scaffold hopping in lead generation: a medicinal chemistry perspective. Drug Discovery Today, 12(3-4), 149-155. https://doi.org/10.1016/J.DRUDIS.2006.12.003 